\title{
Hubungan Pola Makan dengan Kejadian Anemia pada Ibu Hamil di Wilayah Kerja Puskesmas Buleleng III
}

\author{
Wigutomo Gozali * \\ Jurusan D3 Kebidanan Fakultas Olahraga dan Kesehatan Universitas Pendidikan Ganesha
}

\author{
A R T I C L E I N F O \\ Article history: \\ Received 19 May 2018 \\ Received in revised form \\ 10 June 2018 \\ Accepted 28 July 2018 \\ Available online 25 August \\ 2018 \\ Kata Kunci: \\ Ibu hamil, anemia, pola \\ makan \\ Keywords: \\ pregnant woman, anemia \\ food pattern.
}

\begin{abstract}
A B S T R A K
Pola makan merupakan berbagai infromasi yang memberikan gambaran mengenai macam dan jumlah bahan makanan yang dikonsumsi setiap hari oleh satu orang. Pola makan yang kurang baik menjadi salah satu penyebab terjadinya anemia pada masa kehamilan karena kurangnya konsumsi makanan yang mengandung zat besi. Anemia pada ibu hamil akan mengakibatkan peningkatan risiko pendarahan pada saat persalinan dan berat badan bayi lahir rendah. Pada penelitian ini menganalisa tentang hubungan pola makan dengan kejadian anemia pada ibu hamil. Penelitian ini merupakan jenis penelitian korelasional dengan pendekatan cross sectional. Variabel dependen pada penelitian ini adalah pola makan, sedangkan variabel independennya yaitu anemia pada ibu hamil. Pengambilan sampel menggunakan total sampling dengan jumlah sampel sebanyak 25 orang. Pengumpulan data dilakukan dengan kuesioner dan pemeriksaan $\mathrm{Hb}$ (haemoglobin) ibu hamil menggunakan meode sahli. Analisa data menggunakan uji statistik korelasi pearson product moment. Hasil penelitian ini menunjukkan sebagain besar 17 (68\%) responden mengalami anemia ringan dan $11(44 \%)$ responden memiliki pola makan yang cukup. Pola makan pada ibu hamil berhubungan
\end{abstract} bermakna dengan kejadian anemia $(p<0,05)$. Hubungan antara pola makan dengan kejadian anemia kuat, dengan intrepretasi semakin kurang pola makan ibu hamil maka kejadian anemia semakin tinggi. Ibu hamil diharapkan memiliki pola makan yang baik sesuai jumlah kebutuhan pada masa kehamilan.

\section{A B S T R A C T}

Diet is a variety of infromasi that provides an overview of sorts and the amount of food consumed daily by one. Eating less well causes of the anemia in pregnancy because of the lack of food consumption containing iron. Anemia for pregnant women will lead to increased risk bleeding when childbirth and weight baby low birth. In this research analyst about the relationship with dietary pattern and anemia for pregnant women. The research is the kind of research the correlational cross sectional. Dependent variable on research is diet, and independent variable is anemia for pregnant women. The sample total of sampling use of samples from 25 people. Data collection with the questionnaire and $\mathrm{Hb}$ test pregnant women using sahli method. Analysis of data using the statistical perarson correlation product moment. This research result indicates most of 17 (68\%) respondents experienced mild anemia and $11(44 \%)$ respondents adequate eating. Dietary pattern for pregnant women associated with anemia $(p<0,05)$. The relation between dietary pattern and anemia is strong with interpretation the poor dietary pattern, the anemia would be higher. Pregnant women are expected to have a good diet according to the type and amount of required in pregnancy.

Copyright (C) Universitas Pendidikan Ganesha. All rights reserved.

\footnotetext{
* Corresponding author.

E-mail addresses: wigutomogozali@gmail.com (Wigutomo Gozali)
} 


\section{Pendahuluan}

Tingginya angka kematian ibu di Indonesia masih merupakan masalah yang menjadi prioritas di bidang kesehatan. Penyebab langsung kematian ibu terbanyak adalah perdarahan, infeksi, dan keracunan kehamilan. Penyebab kematian langsung dapat bersifat medik maupun non medik. Faktor non medik diantaranya keadaaan kesejahteraan ekonomi keluarga, pendidikan ibu, lingkungan hidup dan perilaku. Faktor-faktor tersebut akan mempengaruhi status kesehatan ibu, dimana status kesehatan ibu merupakan faktor penting penyebab kematian ibu (Amiruddin, 2007). Penyakit dan status gizi yang buruk turut mempengaruhi status kesehatan ibu. Salah satu kematian obstetrik tidak langsung pada kasus kematian ibu adalah anemia. Menurut Mariana (2018) Anemia juga merupakan salah satu masalah gizi utama di Indonesia. Resiko anemia gizi besi ini dapat menyebabkan produktivitas kerja rendah, daya tahan tubuh terhadap penyakit menurun, kemampuan belajar anak sekolah rendah, peningkatan bobot badan ibu hamil rendah dan kelahiran bayi premature. Anemia dalam kehamilan adalah suatu keadaan diamana kadar hemoglobin (Hb) dalam darah kurang dari 10 gr/dl (Wasnidar, 2009).

Anemia adalah gejala dari kondisi yang mendasari, seperti kehilangan komponen darah, elemen tidak adekuat atau kurangnya nutrisi yang dibutuhkan untuk pembentukan sel darah merah yang mengakibatkan penurunan kapasitas pengangkut oksigen darah (Utami 2015). Anemia disebabkan defisiensi beberapa zat gizi seperti zat besi, dan vitamin B12. Anemia gizi pada masa kehamilan sering diidentikkan dengan anemia zat besi. Setiap ibu hamil harus memiliki status gizi yang baik dengan pola makan yang teratur dan bergizi seimbang. Gizi seimbang yaitu pola makan sehari-hari yang sesuai dengan kebutuhan gizi setiap individu untuk hidup sehat dan produktif. Menurut Arisman, dkk, (2007) penyebab Anemia selama kehamilan adalah sebagai berikut : a) Kurangnya mengkonsumsi makanan yang kaya akan zat besi, terutama yang berasal dari sumber hewani yang mudah diserap, b) Kekurangan zat besi karena kebutuhan zat besi yang meningkat seperti pada kehamilan, c) Kehilangan zat besi berlebihan pada perdarahan termasuk saat haid berlebihan, sering melahirkan dengan jarak yang dekat, d) Pemecahan eritrosit yang terlalu cepat (hemolisis)

Pola makan yang tidak seimbang akan menyebabkan ketidakseimbangan zat gizi yang masuk kedalam tubuh dan dapat menyebabkan terjadinya kekurangan gizi atau sebaliknya pola konsumsi yang tidak seimbang juga mengakibatkan zat gizi tertentu berlebih dan menyebabkan terjadinya gizi lebih (Waryana, 2010). Pada ibu hamil terdapat penambahan kebutuhan zat gizi di setiap trimester. Pola makan yaitu gambaran mngenai amcam dan jumlah bahan makanan yang dimakan tiap hari oleh satu orang (Santoso, 2010). Agar mencapai gizi seimbang maka setiap ibu hamil diharapkan mengonsumsi minimal satu jenis makanan yang bersumber dari bahan makanan karbohidrat, protein hewani, protein nabati, sayuran dan buah, selain itu jumlah makanan disesuikan dengan kebutuhan ibu hamil (Santoso, 2004). Petunjuk pola makan yang sehat adalah makanan yang dikonsumsi memiliki jumlah kalori dan zat gizi yang sesuai dengan kebutuhan seperti karbohidrat, lemak, protein, vitamin, mineral, serat dan air. Selain itu, pola makan harus diatur secara rasional, yaitu 3 kali sehari (pagi, siang dan malam). (Krisnatuti, 2005). Zat-zat yang dibutuhkan ibu Hamil meliputi a) Kalori, b) Asama Folat, c) Protein, d) Kalsium, e) Vitamin, f) zat Besi, g) Vitamin C, h) Vitamin D

Faktor-faktor yang mempengaruhi Pola makan adalah pengetahuan, budaya setiap daerah, sosial ekonomi dan lingkungan social, Pencegahan dan perawatan ibu hamil dengan anemia dapat dilakukan dengan perbaikan pola makan dan kebiasaan makan yang sehat serta mengkonsumsi bahan kaya protein, zat besi dan asam folat pada saat kehamilan. Walaupun wanita hamil berhenti menstruasi, tambahan besi tetap diperlukan untuk fetus, plasenta dan peningkatan volume darah ibu. Jumlah ini mendekati $1000 \mathrm{mg}$ besi, lebihbesar ketika memasuki awal kehamilan. Kebutuhan per hari selama kehamilan meningkat dari 0,8 per hari dalam trisemester pertama naik menjadi $6.3 \mathrm{mg}$ per hari dalam trisemester ketiga. Intervensi yang paling mudah dan paling luas jangkauannya adalah melalui institusi Posyandu dan Puskesmas (Prawiirohardjo, 2006)

Prevalensi anemia pada ibu hamil di Indonesia cukup besar yaitu 20-80 \%. Berdasarkan laporan KIA Dinas Kesehatan Provinsi Bali tahun 2006 terdapat 2,32\% ibu hamil mengalami anemia dari 67187 orang ibu hamil. Dari laporan KIA Dinas Kabupaten Buleleng bahwa tahun 2006 terdapat 11693 orang ibu hamil, dimana 336 orang (2,9\%) diantaranya menderita anemia. Laporan KIA tahun 2006 di Puskesmas Buleleng III terdapat 3,6 persen dari 786 ibu hamil mengalami anemia. Persalinan pada wanita dengan anemia defisiensi besi dapat menyebabkan 12 28\% angka kematian janin, 30\% kematian perinatal dan 7 $10 \%$ angka kematian neonatal (Riswan, 2003). Dinas kesehatan Provinsi Bali maupun Kabupaten Bulelenng menargetkan tidak ada ibu hamil yang menderita anemia. Banyaknya ibu hamil yang menderita anemia disebabkan oleh asupan gizi dan pola maka yang kurang baik. Konsumsi makanan yang mengandung zat besi sangat dibutuhkan oleh ibu dan janin. Pada masa kehamilan diperlukan tambahan zat besi sebesa 9 gram pada trimester dua dan 13 gram pada trimester tiga. Anemia pada ibu hamil dapat 
menyebabkan risiko persalinan prematuritas meningkat, kelahiran bayi berat lahir rendah (BBLR), risiko perdarahan sebelum dan saat persalinan, serta infeksi pada masa nifas yang berakibat kematian ibu dan janinnya (Manuaba, 2005). Pada ibu hamil yang menderita anemia ditandai dengan keluhan cepat lelah, sering, pusing, dan mata berkunang-kunang (Depkes RI, 2004). Penyebab paling umum dari anemia pada kehamilan adalah kekurangan zat besi, asam folat, dan perdarahan akut dapat terjadi karena interaksi antara keduanya (Noverstiti, 2012)

Dalam mengatasi masalah anemia pada ibu hamil, pemerintah memiliki program pemberian tablet Fe secara rutin minimal 90 tablet selama masa kehamilan, serta memberikan penyuluhan mengenai kebutuhan gizi dan pola makan yang baik pada masa kehamilan (Depkes RI,2004). Setiap individu memiliki pola makan yang berbeda-beda karena pola makan ini berhubungan dengan kondisi wilayah, soaial budaya dan kebiasaan hidup (Santoso,2004). Pola makan yang kurang tepat pada ibu hamil masih banyak dijumpai di masyarakat kita. Melihat permasalahan di atas peneliti tertarik meneliti tentang hubungan pola makan terhadap kejadian anemia pada ibu hamil di Desa Alasangker Wilayah Kerja Puskesmas Bulelelng III Kabupaten Buleleng. Karena masih tingginya kejadian anemia di wilayah tersebut.

\section{Metode}

Jenis penelitian ini adalah kolerasional yang berfungsi untuk mengkaji hubungan antar variabel, yang bertujuan mengungkapkan hubungan korelatif antar variabel, hubungan korelatif mengacu pada kecenderungan bahwa variasi suatu variabel diikuti oleh variabel yang lain. Peneliti dapat mencari, menjelaskan suatu hubungan, memperkirakan, menguji berdasarkan teori yang ada (Nursalam, 2001). Penelitian ini menggunakan pendekatan cross sectional dimana pada penelitian ini variabel sebab akibat yang terjadi pada obejek penelitian secara simultan dalam waktu yang bersamaan, untuk memperoleh data yang lebih lengkap dilakukan dengan cepat (Notoatmodjo, 2002).

Penelitian ini dilakukan di Desa Alasangker Wilayah Kerja Puskesmas Buleleng III, Kecamatan Buleleng, Kabupaten Buleleng karena di wilayah ini masih banyak terdapat ibu hamil anemia. Populasi adalah keseluruhan obyek penelitian atau obyek yang akan diteliti (Notoatmojo, 2005). Populasi penelitian ini adalah seluruh ibu hamil yang berada di Desa Alasangker Wilayah Kerja Puskesmas Buleleng III . Sampel adalah sebagian dari keseluruhan obyek yang diteliti dan dianggap mewakili seluruh populasi (Notoatmojo, 2005). Teknik sampling yang digunakan pada penelitian ini adalah Nonprobability Sampling yaitu Total Sampling. Total sampling adalah teknik penentuan sampel bila semua anggota populasi digunakan sebagai sampel atau responden. Seluruh ibu hamil di Desa Alasangker sebanyak 31 orang menjadi sampel atau responden pada penelitian ini. Data yang diambil yaitu karakteristik dan pola makan responden dengan bantuan kuesioner serta kadar Hb menggunakan metode sahli.

\section{Hasil dan pembahasan}

Dari 25 responden, yang memiliki pola makan yang sangat baik adalah sebanyak 3 (12\%) responden, pola makan baik sebanyak $9(36 \%)$ responden, pola makan yang cukup $11(44 \%)$ responden, dan pola makan kurang $2(8 \%)$ responden. Sebagai responden memiliki pola makan yang cukup mengkonsumsi makanan 3 kali makan dalam sehari, jenis makanan yang dikonsumsi yaitu nasi, lauk, sayur, dan buah. Jenis lauk yang dikonsumsi nabati seperti tempe, tahu dan kacang-kacangan serta lauk hewani daging, ikan, hati,udang, olahan. Lauk hewani dan nabati dikonsumsi 3 potong dalam sehari. Makanan ibu hamil memiliki dampak pada kehamilan, pada perkembangan janin dan juga pada kesehatan ibu dan anak. Makanan yang dikonsumsi seorang wanita hamil merupakan sumber utama nutrisi untuk bayi. Hal ini penting bagi wanita hamil untuk memahami apa jenis makanan yang terbaik bagi mereka serta bayi mereka karena dapat melindungi kesehatan ibu dan memberikan pertumbuhan optimal dan perkembangan bayi yang dikandungnya.

Dari 25 responden, yang tidak mengalami anemia sebanyak 8 (32\%) responden, anemia ringan sebanyak 17 (68\%) responden dan tidak ada responden yang mengalami anemia berat. Anemia pada ibu hamil merupakan suatu keadaan terjadinya kekurangan zat besi dalam tubuh ibu hamil dimana kadar $\mathrm{Hb}$ kurang dari 11 gram \%. Berdasarkan hasil penelitian sebagai besar responden mengalami anemia ringan (Hb 8-11 gram \%). Menurut Astuti (2018) meningkatnya kejadian anemia dengan bertambahnya umur kehamilan disebabkan terjadinya perubahan fisiologis artinya, semakin besar usia kehamilan maka kadar $\mathrm{Hb}$-nya semakin rendah. Semakin rendahnya kadar Hb mengimplikasikan semakin besarnya resiko menderita anemia. Selain karena asupan makanan yang kurang, hal ini juga disebabkan oleh tingkat pendidikan responden menengah ke bawah (SD dan SMP) yaitu 14 orang (56\%) responden. Menurut Mubarak (2006) makin tinggi tingkat pendidikan seseorang semakin mudah menerima informasi sehingga makin banyak juga pengetahuan yang dimiliki. 
Terdapat hubungan yang signifikan $(\mathrm{p}<0,05)$ pola makan dengan kejadian anemia pada ibu hamil. Dari koefisien $r$ hitung $=0,93$ (93\%). Hal ini berarti 93\% anemia dipengaruhin oleh pola makan. Sedangkan 7\% disebabkan oleh faktor lain. Terdapat hubungan kuat negatif antara pola makan dengan kejadian anemia $r=0,964$. Hal ini sesuai dengan pendapat bahwa semakin kurang baik pola makan maka akan semakin tinggi angka kejadian anemia pada ibu hamil (Amiruddin, 2007). Pola makan yang baik bagi ibu hamil harus memenuhi sumber karbohidrat, protein dan lemak serta vitamin dan mineral, yang disesuaikan dengan kebutuhan selama masa kehamilan (Budiyanto, 2002). Pola makan disini menyangkut jenis dan jumlah makanan, dimana jenis dan jumlah makanan yang harus dipenuhi pada masa kehamilan yaitu nasi/pengganti 4-5 1/2 piring, lauk hewani 4-5 potong, lauk nabati 2-4 potong sayuran 2-3 mangkok, buah-buahan 3 potong, minum air tidak kurang dari 8 gelas perhari. Pola makan yang kurang baik merupakan salah satu faktor terjadinya anemia pada masa kehamilan terutama karena kurangnya konsumsi makanan yang kaya akan zat besi (Depkes RI, 2004). Pada masa kehamilan sering terjadi kekurangan zat besi sehingga terjadi penurunan kadar $\mathrm{Hb}$ yang disebabkan oleh hermodilusi dalam tubuh ibu hamil dan kurang baiknya pola makan serta konsumsi makanan yang mengandung zat besi. Hasil penelitian ini sejalan dengan penelitian yang dilakukan oleh Pertiwi (2013) yang menunjukkan bahwa terdapat hubungan antara pola makan dengan kejadian anemia pada ibu hamil di wilayah kerja Puskesmas Kerjo Kabupaten Karanganyar. Hasil penelitian sejalan dengan penelitian Suranto (2013), dengan judul hubungan antara pola makan dengan terjadinya anemia pada ibu hamil di Puskesmas Dawe Kecamatan Dawe Kabupaten Kudus, dengan hasil penelitian sebagian besar ibu hamil memiliki kuantitas makanan dalam kategori kurang sebanyak (46,9\%), sebagian besar ibu jenis makanan kurang (50\%), sebagian besar cara memasak makanan ibu hamil dalam kategori kurang $(46,9 \%)$, dan ada hubungan kuantitas, jenis makanan dan cara memasak makanan dengan terjadinya anemia pada ibu hamil di Puskesmas Dawe Kecamatan Dawe Kabupaten Kudus.

Dan didukung juga penelitian Pertiwi (2013), dengan judul hubungan antara pola makan dengan kejadian anemia pada ibu hamil di Wilayah Kerja Puskesmas Kerjo Kabupaten Karanganyar, dengan hasil penelitian 49\% ibu hamil memiliki kebiasaan makan utama $<3$ kali sehari, 16,3\% ibu hamil mengkonsumsi kurang dari 5 jenis makanan sehari, 36,7 ibu hamil mengalami anemia dan 63,3\% tidak anemia, ada hubungan antara frekuensi makan denga kejadian anemia $(\mathrm{p}=0,002)$, ada hubungan antara jenis makanan dengan kejadian anemia $(\mathrm{p}=0,01)$, dan disimpulkan hasil penelitian terdapat hubungan pola makan dengan kejadian anemia pada ibu hamil. Hasil penelitian ini sejalan dengan penelitian Sandrayayuk dkk (2013), dengan judul hubungan pola makan dengan kejadian anemia pada ibu hamil trimester III di Puskesmas Pleret Bantul, dengan hasil ada hubungan pola makan dengan kejadian anemia pada ibu hamil trimester III di Puskesmas Pleret Bantul. Dengan 43,3\% ibu hamil pola makan baik, 50\% ibu hamil pola makan sedang 6,7\% ibu hamil pola makan kurang, 43,3\% ibu hamil tidak anemia, 53,3\% ibu hamil anemia ringan, 3,3 \% ibu hamil anemia sedang.

\section{Simpulan dan saran}

Berdasarkan hasil penelitian dapat disimpulkan sebagai berikut: 1) Sebagian besar ibu hamil memiliki pola makan cukup yaitu sebanyak 11 (44\%) responden, 2) Ibu hamil yang mengalami anemia ringan sebanyak 17 (68\%) responden, 3). Terdapat hubungan yang signifikan antara pola makan dengan kejadian anemia pada ibu hamil di Desa asalangsker, Kecamatan Buleleng, Kabupaten Buleleng. Ibu hamil diharapkan memiliki pola makan yang baik sesuai jenis dan jumlah kebutuhan pada masa kehamilan.

\section{Daftar Rujukan}

Amiruddin, R., Wahyuddin (2007). Studi kasus kontrol faktor biomedis terhadap kejadian anemia ibu hamil di Puskesmas Bantimurung. Jurnal Medika Nusantara Vol. 25 No. 2.

Arisman, dkk, 2003. Anemia Defisiensi Zat Besi pada Ibu Hamil di Indonesia (Evidenced Based). Diakses tanggal 14 Pebuari 2012. http://ridwanamiruddin.wordpress.com

Astutia, Dwi, Ummi Kulsumb. 2018. POLA MAKAN DAN UMUR KEHAMILAN TRIMESTER III DENGAN ANEMIA PADA IBU HAMIL. Indonesia Jurnal Kebidanan Vol. 2 No.1 (2018) 24-30

Budiyanto,M. Dasar-Dasar Ilmu Gizi.Jakarta.EGC.2002

Departemen Kesehatan.Perawatan Kesehatan Masyarakat. Jakarta.2004. 
Hendrayani, M. D., Sawitri, A. A. S., Karmaya, M.Perilaku Pemeriksaan Antenatal sebagai Faktor Risiko Anemia Gizi Ibu Hamil di Puskesmas II Denpasar Selatan Tahun 2012. Public Health and Preventive Medicine Archive. 1 (1); 2013.

Krisnatuti., 2005, Anemia pada ibu hamil . Diakses 29 Januari 2013, dari http://content.nejm.org/cgi/content/full/34 5/11/790

Manuaba, IB. Ilmu Kebidanan, Penyakit Kandungan Dan Keluarga Berencana.Jakarta.EGC.2005.

Mariana, Dina, Dwi Wulandari, Padila. 2018. Hubungan Pola Makan Dengan Kejadian Anemia Pada Ibu Hamil Di Wilayah Kerja Puskesmas. Jurnal Keperawatan Silampari (JKS) Volume 1, No 2, JanuariJuni 2018 pp 108-122.

Mubarak,W.I, dkk. Buku Ajar Ilmu Komunitas 2, Teori dan Aplikasi Dalam Praktek .Jakarta. CV. Agung Seto.2006.

Notoadtmodjo,S.Metodelogi. 2002. Penelitian Kesehatan.Jakarta.Rineke Cipta.

Noto Admodjo, 2003, Metodelogi Penelitian Kesehatan, Jakarta Eka Cipta.

Noto Admodjo, 2005 Kesehatan Masyarakat dan Promosi Kesehatan, Jakarta Eka Cipta

Noverstiti,Elsy.(2012).Faktor-faktor yang Berhubungan dengan Kejadian Anemiapada Ibu HamilTrimester III di Wilayah Kerja Puskesmas Air Dingin Kota Padang tahun 2012. STIKES Peringsewu Lampung.

Nurhidayati, A., Erlyn, H. 2014. Hubungan Asupan Nutrisi dengan Kadar Hb pada Ibu Hamil di BPS Suratini Suwarno Surakarta. Jurnal KesMaDaSka. Januari: 21 - 27

Nursalam dan Pariani.Metodelogi Riset keperawatan. Jakarta. CV.Infomedika.2001.

Pertiwi, Aldila Septiana. 2013. Hubungan Antara Pola Makan Dengan Kejadian Anemia Pada Ibu Hamil Di Wilayah Kerja Puskesmas Kerjo Kabupaten Karanganyar. Jurnal Program Studi Gizi Fakultas Ilmu Kesehatan Universitas Muhammadiyah Surakarta.

Prawirohardjo 2006, Statisk untuk Penelitian Kesehatan, Bandung Alfa Beta

Riswan, M. 2003. Anemia Defisiensi Zat Besi Pada Wanita Hamil Dibeberapa Praktik Bidan

Sandrayayuk, M, Benny, W, Jolie S. (2013) Hubungan Status Gizi Dengan Kejadian Anemia Pada Ibu Hamil Di Wilayah Kerja Puskesmas Tuminting Kec. Tuminting Kota Manado. Ejournal Keperawatan.

Salman, Y., Ideris, Siti, M. M. 206. Hubungan Pola Konsumsi Zat Besi dan Kepatuhan Mengkonsumsi Tablet Fe dengan Kejadian Anemia pada Ibu Hamil di Wilayah Kerja Puskesmas Sambung Makmur Tahun 2015. Jurkessia. 6 (2): $51-58$

Santoso, S. Kesehatan Dan Gizi.Jakarta.PT.Bhineka Cipta.2004.

Setyawati B, Syauqy A. (2013). Perbedaan Asupan Protein, Zat Besi, Asam Folat, dan Vitamin B12 Antara Ibu Hamil Trimester III Anemia dan Tidak Anemia di Puskesmas Tanggungharjo Kabupaten Grobogan. Journal of Nutrition College, Vol 3, No1. 2014. P 228-234 dalam situs. http://ejournals1.undip.ac.id/index.php/jnc. diakses tanggal 12 Juni 2017.

Utami, Baiq Nurlaily, Surjani , Eko Mardiyaningsih. 2015. Hubungan Pola Makan Dan Pola Menstruasi Dengan Kejadian Anemia Remaja Putri. Jurnal Keperawatan Soedirman (The Soedirman Journal of Nursing), Volume 10, No.2.

Wahyuningsih, Ida Sri, Sri EndangWahyuningsih. 2013. HUBUNGAN POLA MAKAN DENGAN KEJADIAN ANEMIA PADA IBU HAMIL DI BIDANPRAKTIK MANDIRI KABUPATENDEMAK. Dinamika Kebidanan vol.3no.1 
Wasnidar T. Buku Saku Anemia pada Ibu Hamil dan Konsep Penatalaksanaan. Jakarta: Trans Info Media; 2009

Waryana . 2010. Gizi Reproduksi. Yogyakarta : Pustaka Rihan.

Zubir. 2018. Hubungan Pola Makan dengan Kejadian Anemia pada Remaja Putri SMK Kesehatan AsSyifa School Banda Aceh. Serambi Saintia, Vol. VI, No. 2 